\title{
Correlation Between Social Compliance and Export Competitiveness in the RMG Industry of Bangladesh
}

\author{
Mukit Ahmed $^{1} \quad$ Shishank Shishank $^{1} \quad$ Md. Faruque Hossain ${ }^{2, *}$ \\ 1.Department of Management, Birmingham City University, UK \\ 2.OSCM, Faculty of Business Administration, American International University-Bangladesh
}

\begin{abstract}
Having survived one disaster after another, the Readymade Garments (RMG) industry of Bangladesh progressed swiftly, becoming the second-largest exporter of textiles and clothing. Prior to remediation programs launched by Accord-Alliance in the aftermath of the Rana Plaza incident, RMG companies have not been as keen about social compliance as they are now. Therefore, this research seeks to investigate the correlation between social and export competitiveness. Sales data of fifty-two RMG companies over the last five years were collected and analysed to determine the sales trend. The results of the analysis show there is an upward trend in the sales data. This means social compliance has not affected sales revenue. On the contrary, the results confirm what the literature states social compliance attracts more export orders. A thorough literature review led to the development of a hypothesis stating social compliance and export competitiveness have a positive correlation. There are, however, other factors to consider when discussing export competitiveness such as lead time management, supply chain management, government's fiscal policies, trade pacts, port efficiencies, energy supplies, cotton imports, backward and forward linkages, tariff and currency depreciation affect competitiveness of cotton exports. Shortening the lead time can boost export competitiveness of Bangladeshi textiles and clothing in the long run. Implementing supply chain management systems will help to optimize lead time and developing the local backward linkage industry will curb exporters' dependence on imported raw materials and thereby shorten lead time further. However, further research along with primary data will provide the accuracy and relevance required for a research of this scope.
\end{abstract}

Keywords: Readymade Garments, Social Compliance, Export Competitiveness, Bangladesh.

DOI: $10.7176 / \mathrm{JESD} / 11-9-04$

Publication date:May $31^{\text {st }} 2020$

\section{INTRODUCTION}

Disproving Henry Kissinger's pessimistic observations on Bangladesh's economic prospects, the RMG industry helped the politically fragile nation recover from its post-independence economic hardships. Replacing jute producers as the top foreign exchange earner, textile companies were welcomed by a conservative and impoverished population who switched from farm work to factory jobs overnight. The apparel sector's steady growth led to job creation and poverty alleviation for unskilled (and previously unemployed) blue collar workers.

The export quota systems like the Generalised System of Preferences (GSP) and Multi-Fibre Arrangement (MFA) enabled Bangladesh to build a global customer base for its exports of readymade garments. The little known South Asian country also capitalized on a local supply of cheap labour. Without this advantage, it would have been difficult to compete with rivals like China and Vietnam. China dominates the RMG export market to this date despite declining exports and Vietnam's rising exports have made it a close contender to Bangladesh (Hossain et al., 2019). The RMG include both knitwear and woven products such as, socks, undergarments, sweaters, cardigans, and stockings are part of the knitwear portfolio; whereas shirts, T-shirts, skirts, blouses, and trousers are some of the woven products manufactured by RMG factories in Bangladesh (Haider, 2007). The bulk of this output is exported. From more than 100 countries across the globe that buy apparels made in Bangladesh, USA and EU are the biggest importers of Bangladeshi readymade garments (Hossain et al., 2019).

In recent years, however, there are growing concerns about Bangladesh's dependence on these two countries for its textile exports. As Chinese and Indian readymade garments command an increasing share of the export market in North America and West Europe, there is a greater need for market diversification to sustain Bangladesh's top export earning industry (Haider, 2007). A group of researcher argue that the Netherlands, Japan, and Poland are potential export markets for apparels in the coming years (Hossain et al, 2019). Bangladeshi textile companies should tap into these promising geographic segments to boost its market share. They also claim product diversification has given China and India a competitive edge in the international apparels market. Therefore, Bangladesh's RMG manufacturers should study market trends and respond to changes in demand for different categories of readymade garments.

With the end of export quotas and the emergence of new competition, apparel manufacturers in Bangladesh are becoming desperate to meet profit targets. The RMG exporters have resorted to cost cutting strategies at the expense of ethical labour practices. Recent incidents which claimed the lives of factory workers and injured many more are the culmination of years of neglect by factory owners (Nasreen, 2019). Eager to continue production and maintain profitability at the same time, factory owners have paid little or no attention to factory safety and 
employee welfare. In one incident, the structural integrity of the building was compromised, causing the building to collapse and kill the workers inside. Those who survived have been handicapped for life, and are no longer able to work and provide for their families. Another incident was triggered by inadequate fire safety measures. Workers could not escape the burning building because fire exits were blocked, as a result ended up with death (Aka, 2019). These unfortunate, but preventable, incidents provoked both domestic and international outrage. Importers of Bangladeshi readymade garments launched inspection and remediation programmes called Accord and Alliance for textile businesses in Bangladesh (Uddin, 2018). These privately formed regulatory bodies ensure that Bangladeshi factories producing readymade garments for exports are abiding by the work safety and labour rights conventions of International Labour Organisation (ILO). Some foreign buyers are now stipulating conformity to ISO standards, ETI Base Code, and/or FLA recommendations in their contracts.

Since 2018, subcontracting restrictions have been imposed, making it harder for small and medium companies to survive (Mirdha, 2019). In the past, small and medium enterprises (SMEs) tried to compensate for the shortfall in export orders through subcontracting operations. Larger factories outsourced production to these subcontractors during peak periods ignoring labour rights violations committed by them. Many subcontractors are guilty of sweatshop conditions in their factories where illiterate labourers work for long hours and below minimum wages. Workers are unaware of their rights as employees and are driven by poverty to accept jobs in these factories. Small and medium textile firms are the greatest violators of labour rights and factory safety. Their poor compliance record stems from an inability to survive price competition in the export market. The start-up cost for the RMG factory is so high, small and medium apparel manufacturers are unable to recoup the initial investment even after several years of operation. In 2018-2019, more than 100 small and medium factories were closed down due to compliance issues and more than 50,000 workers were laid off as a result. The factories' failure to follow occupational health and safety guidelines was attributed to high production costs (Mirdha, 2019).

There are costs involved in meeting occupational health and safety requirements such as investments in fire safety equipment, literature on fire hazards for workers, fire safety training, installation of fire exits, first aid supplies, health insurance, fair wages, paid sick leave, separate toilets, etc. Although most of these costs are oneoff, they are beyond the reach of SMEs which have limited access to seed capital. They also have difficulty managing their working capital and struggle to pay wages on time. Evidently, the costs of compliance will become a financial burden for companies grappling with low export prices. The costs incurred by compliant firms in the apparels sector are: start-up cost, initial cost of compliance, production cost, running cost of compliance. The initial cost of compliance includes as, installing green machinery (i.e. those that save water, electricity, and gas), installing fire safety equipment and gear, installing fire exits, installing an adequate number of toilets for both male and female employees, relocating to the suburbs or industrial zones (for factories located in city centres), creating clearly demarcated spaces inside the factory for pregnant and breastfeeding workers to take breaks. The running cost of compliance includes as, paying the basic minimum wage to factory workers, providing health insurance for shop floor employees, providing food, clean drinking water, medicine, and first aid for staff members, training management on occupational health and safety, educating factory workers on fire safety, how to use the fire extinguisher, and what to do when the building catches a fire, fumigating the premises during an epidemic. The organizations responsible for monitoring compliance of textile factories in Bangladesh with international standards on occupational health and safety and labour rights are: International Labour Organization (ILO), International Standardization Organization (ISO), Worldwide Responsible Accredited Production (WRAP), Business Social Compliance Initiative (BSCI), Ethical Trading Initiative (ETI), Fair Labour Association (FLA), and Fair Wear Foundation (FWF).

These organizations assess textile companies on social compliance and certify companies that have a proven track record of conforming to ethical labour practices or industrial codes of conduct formulated by the respective accreditation bodies. The ETI Base Code, for example, is a globally accepted code of ethical practice based on ILO conventions which cover aspects of ethical business practice such as, a worker's right to freedom of association and collective bargaining, safe and hygienic working conditions, saying 'no' to child labour, paying wages on time and reasonable working hours. The ILO's core labour standards make the use of child labour, bonded or forced employment, curbs on freedom of association and collective bargaining, and discrimination punishable offences for RMG factories anywhere in the world. Working conditions in these factories must also conform to ILO and FLA guidelines. Wages must be paid on time and cover living expenses sufficiently. Working hours should not exceed the recommended limit. Workers are entitled to paid leaves and holidays. Factory management must exercise zero tolerance for cases of harassment and abuse and ensure a safe working environment particularly for female employees. Management systems and training are vital for the implementation of occupational health and safety guidelines. They will also facilitate smooth industrial relations, protect women's rights, and preserve the environment.

Green industrialization is being advocated by an increasing number of compliance bodies. Environmental activists are campaigning for eco-friendly equipment and processes in factories. Bangladesh Bank (BB) created the Green Transformation Fund (GTF) to subsidize machinery upgrades for small and medium enterprises in the 
apparels sector. With this financial assistance, factories can build capacity by acquiring machinery that will use less water, gas, and electricity (Hossain et al., 2019). However, the fund is not big enough to accommodate all textile companies that are needed, leaving most of them with machinery that is depleting the planet's scarce resources. If occupational health and safety requirements are not met by RMG factories in Bangladesh, it will set a bad precedent for other industries in the country. Considering the challenges faced by RMG firms especially SMEs in securing institutional loans, it is believed government and industry support can alleviate the additional burden of compliance costs and thereby sustain the export competitiveness of these firms. More than 5,000 RMG factories operating in Bangladesh are compliant and most textile companies in this country view compliance as a necessary evil. Several authors argues this line of thinking is false because compliance has priority over product quality in securing export orders (Ahmed et al., 2013; Hossain et al., 2014; Hossain and George, 2014; Rahman et al., 2017; Hossain et al., 2019; Mirdha, 2019); therefore, this research main objective is to examine the relationship between social compliance and export competitiveness in the RMG industry of Bangladesh.

\section{Literature Review}

Growing at a rate of $15 \%$ per annum over the last fifteen years, the RMG industry of Bangladesh makes up $16 \%$ of GDP (Ahmed et al., 2013; Rahman et al., 2017). It has provided five million direct jobs for more than twentyfive years (Hasan et al., 2016). Close to $80 \%$ of the nation's foreign exchange earnings in the fiscal year (FY) 2013-2014 came from RMG exports (Rakib and Adnan, 2015). In the 1970s, Bangladesh started producing RMGs on a modest scale (Haider, 2007; Kapuria et al., 2017). It started as a small non-traditional export industry with only nine companies, most of which were joint ventures with Korean companies (Rahman et al., 2017). As the industry grew in capacity and technology during the 1980s, it specialized in woven products. In the 1990s, it diversified into knitted products (Haider, 2007). Woven products include shirts, trousers, and t-shirts; whereas knitted products include polo shirts, socks, stockings, sweaters, and undergarments (Haider, 2007; Rahman et al., 2017). The $95 \%$ of woven products and $90 \%$ of knitted products manufactured in Bangladesh are exported (Adnan et al., 2015). Knitwear accounts for $40 \%$ of the country's total apparel exports and has contributed to $7.2 \%$ of national GDP in the past five years (Rahman et al., 2017). Compared to the woven products sector, the knitwear sector has a relatively strong backward linkage (Nuruzzaman and Haque, 2009; Kader and Akter, 2014; Rakib and Adnan, 2015; Mohibullah et al., 2016). This has created a high potential for foreign direct investment in related sectors such as spinning, weaving, sewing, packaging, and the manufacture of accessories (Habib, 2009). Woven products had high demand in USA, whereas knitwear enjoyed considerable success in EU (Rakib and Adnan, 2015).

There are approximately 4,000 textile factories in Bangladesh (Hasan et al., 2016), located in Dhaka, Narayanganj, and Chittagong, 95\% of these factories are owned and run by Bangladeshi nationals (Fakir et al., 2013). There were more than 300 apparel manufacturing units in FY 1984-85. This number skyrocketed to approximately 6,800 units in FY 2012-13 before dropping to around 4,000 units in FY 2013-14. The number of factories decreased rapidly in FY 2013-14 because the authorities revoked the trade licenses of companies not complying with international labour standards and occupational safety regulations. Despite the closure of these factories, exports of RMGs from Bangladesh increased by 14\% in FY 2013-14 (Rahman et al., 2017).

Export quota systems such as MFA and GSP and the availability of cheap manpower fuelled the rapid growth of the RMG sector. The GSP enabled the industry to penetrate the fiercely competitive American market, whereas the MFA allowed access to European textile markets. The industry also enjoyed preferential tariffs under both systems until December 2014 (Hossain et al., 2019). In the Uruguay round of negotiations in January 1995, the World Trade Organisation's (WTO) Agreement on Textile and Clothing (ATC) phased out the MFA. This was realised in four phases over a period of ten years. The fourth and final phase was concluded on December 31, 2004 (Joarder et al., 2010).

Bangladesh exports RMGs to 161 countries worldwide, of these, USA and EU were the largest importers under MFA (Hossain et al., 2019). Between $80 \%$ and $90 \%$ of textiles manufactured in Bangladesh were exported to these two countries for as long as Bangladesh had preferential market access (Haider, 2007). With MFA and GSP no longer enforceable from January 2015, Bangladesh is now grappling with stiff competition from Chinesemade and Indian-made apparels, which are dominating the American and European markets (Kathuria, 2013). Since the end of the MFA, textile exports from Bangladesh fell by 6.2\% (Joarder et al., 2010). Even before the phase-out of the export quota systems, China had a competitive advantage over Bangladesh. Its export price dropped by $46 \%$ during the fiscal year 2001-2002 making its readymade garments cheaper than those made in Bangladesh. In this period, the price of Bangladeshi apparels was 9,500 Euros per ton; whereas, Chinese apparels cost only 8,800 Euros per ton (Haider, 2007).

Price, however, is not the only competitive advantage China has over Bangladesh. A shorter lead time helps China meet export orders faster than its rivals (Mohibullah et al., 2016). Lead time is the time required to deliver the readymade garments after the export order is placed (Habib, 2009). The globally accepted standard since the early 2000s is 30-40 days, which is a significant departure from the standard lead time of 120-150 days during the 
1980s (Haider, 2007). In both the knitwear and woven product categories, China precedes all other RMG exporting nations with respect to lead time (Kader and Akter, 2014). The Table 1 shows a comparison of the lead times of three international textile producers.

Table 1: Lead Times of RMG Exports (Haider, 2007; Kader and Akter, 2014).

\begin{tabular}{lccc}
\hline \multicolumn{3}{c}{ List of Countries } \\
\hline Knitted Products & China & India & Bangladesh \\
Woven Products & $50-60$ days & $60-70$ days & $60-80$ days \\
\hline
\end{tabular}

The Fig. 1 shows a competitive analysis of the RMG exports of three international textile producers to the US market.

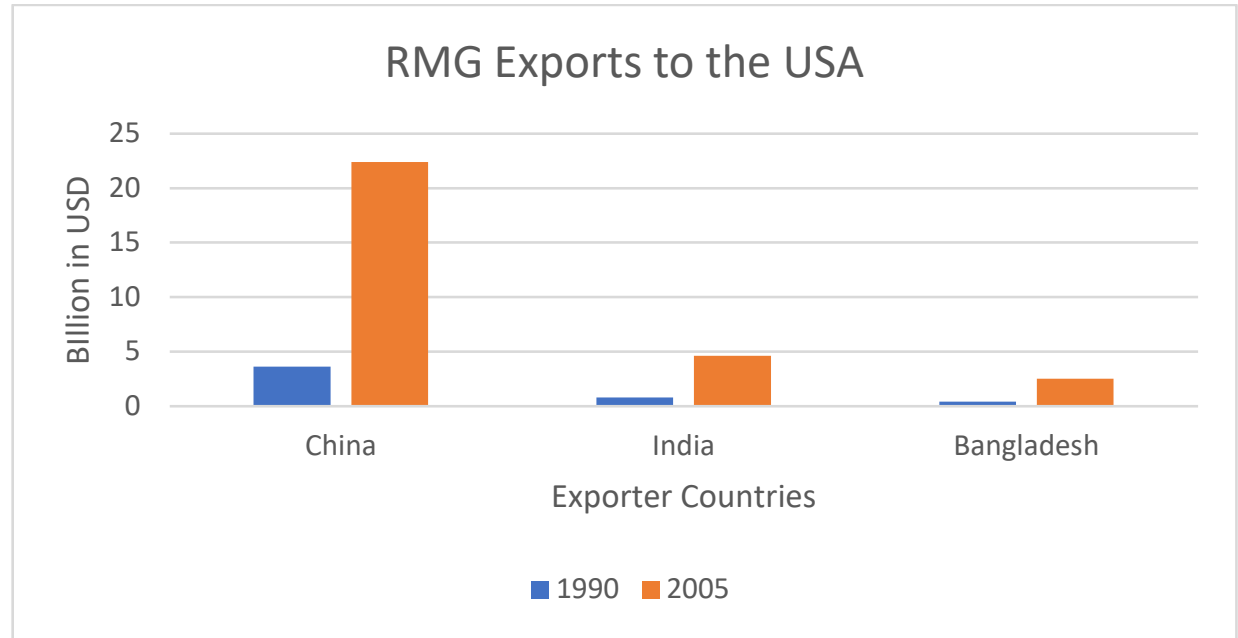

Fig. 1: RMG Exports to the USA (Haider, 2007).

The Fig. 2 shows a competitive analysis of the RMG exports of three international textile producers to the European market.

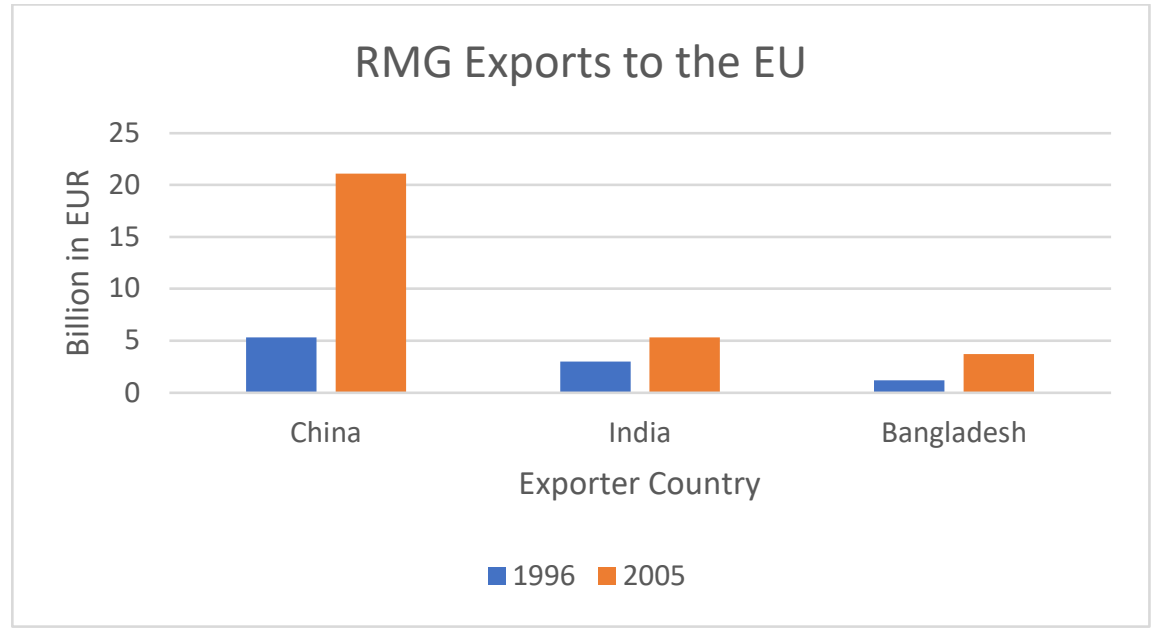

Fig. 2: RMG Exports to the EU (Haider, 2007).

The compliance is more important than product quality from the importer's perspective (Ahamed, 2013). Most of the textile factories operating in Bangladesh are non-compliant and international buyers are concerned about this. There have been 69 reported incidents in the RMG industry which are responsible for 1,626 casualties and 4,829 injured workers during the period 1990-2016 (Hasan et al., 2017). Cheap manpower did not sustain Bangladesh's competitive advantage because overseas buyers revoked orders after apparel manufacturers were found to be non-compliant (Alam et al., 2017). Importers of Bangladeshi readymade garments are now stipulating compliance to international labour standards in contracts (Rahman and Hossain, 2010). The readymade garments sector has seen phenomenal growth until 2005 for two reasons: the export quota systems and the availability of low-cost labour (Haider, 2007). The problems are common in the apparels sector of Bangladesh: unskilled workers, informal recruitment, wage discrimination, irregular disbursement of wages, and temporary service contracts (Rahman (2014). It is also reported that most textile companies in Bangladesh had poor housekeeping, ineffective monitoring mechanisms, haphazard production layout, inadequate lighting and ventilation, and rented premises which were not suitable for textile production. These lapses in social compliance are likely to compromise 
Bangladesh's credibility in the international market which has become increasingly sensitive to labour rights (Rahman and Hossain, 2010).

There is ample evidence to show that more than $90 \%$ of deadly incidents in textile factories are started by a fire (Hasan et al., 2017). Most readymade garments manufacturers in Bangladesh failed to ensure adequate provisions for emergencies such as fire accidents (Chowdhury et al., 2014). Corridors were blocked by storage items, emergency lights were not installed, escape routes did not have neon signs by which employees could identify them, doors of escape routes were not fire-resistant, and fire exits were few in number relative to the staff. Fire equipment present in factories studied by Himi and Rahman (2013) did not work. While Ahamed (2013) concedes that the RMG industry's future depends on satisfying stakeholders and appeasing buyer concerns about social compliance, he also argues that poor infrastructure, lack of resources, and loopholes in government policy make social compliance expensive. The RMGs industry generated USD 22 billion in export income in the fiscal year 2013-2014, which accounted for $81 \%$ of total national export and 16\% of GDP (Rakib and Adnan, 2015). In the fiscal year 2017-2018, it earned USD 30.61 billion from its exports, which accounted for $83.5 \%$ of total export earnings and $11.23 \%$ of GDP (Hossain et al., 2019). Since 2009, China has been the only country to export more than Bangladesh (Alam et al., 2017; Rahman et al., 2019). Bangladesh had a market share of 6.5\% in the year 2017 surpassing previous runner-ups Italy and Hong Kong (Rahman et al., 2019). However, Vietnam, Sri Lanka, and Cambodia are close contenders in the post-MFA era (Joarder et al., 2010). The Table 2 shows a comparative analysis of the market share of countries exporting RMGs.

Table 2: Export Market Share of RMG Exporting Countries (Hossain et al., 2019).

\begin{tabular}{lcc}
\hline Country & Year 2012 $(\%)$ & Year 2016 (\%) \\
\hline China & 36.68 & 33.75 \\
Bangladesh & 4.77 & 7.50 \\
Vietnam & 3.48 & 5.72 \\
Italy & 5.03 & 4.60 \\
Germany & 4.37 & 3.94 \\
India & 3.19 & 3.91 \\
Hong Kong & 5.26 & 3.44 \\
Turkey & 3.43 & 3.40 \\
Spain & 2.30 & 2.83 \\
France & 2.35 & 2.31 \\
\hline
\end{tabular}

Apart from increased competition, the challenges facing Bangladesh's readymade garments sector are high lead time, difficulty of doing business, scarcity of industry-specific skills, high cotton imports, low per capita productivity, and poor compliance among subcontractors (Chowdhury et al., 2006). Supply chain management is vital for boosting the export competitiveness of the RMG industry considering the complexity of international business (Nuruzzaman et al., 2010). In view of the changing market dynamics since the phase-out of MFA, Bangladesh must explore emerging markets for readymade garments such as Japan, Australia, Chile, Eurasia, South America, Middle East, and Russia (Ahmed et al., 2013). Demand for ladies' dresses, stylish cardigans, and baby clothes are rising steadily (Adnan et al., 2015). Bangladeshi apparel manufacturers must adapt to these changing consumer needs by diversifying its product line (Haider, 2007; Rakib and Adnan, 2015; Hossain et al., 2019). The Table 3 shows the growth rate of export markets around the world.

Table 3: Growth Rate of RMG Export Markets Worldwide (Hossain et al., 2019).

$\begin{array}{lc}\text { Country } & \text { Compound Average Growth Rate (CAGR) in \% } \\ \text { 2012-2016 }\end{array}$

Bangladesh should tap into these markets since there is a high potential for exporting readymade garments to these countries. The same research concluded that Bangladesh's share of the apparel market in USA has started to decline and its market share in EU is gradually increasing. The following chart illustrates this scenario (Fig. 3). 


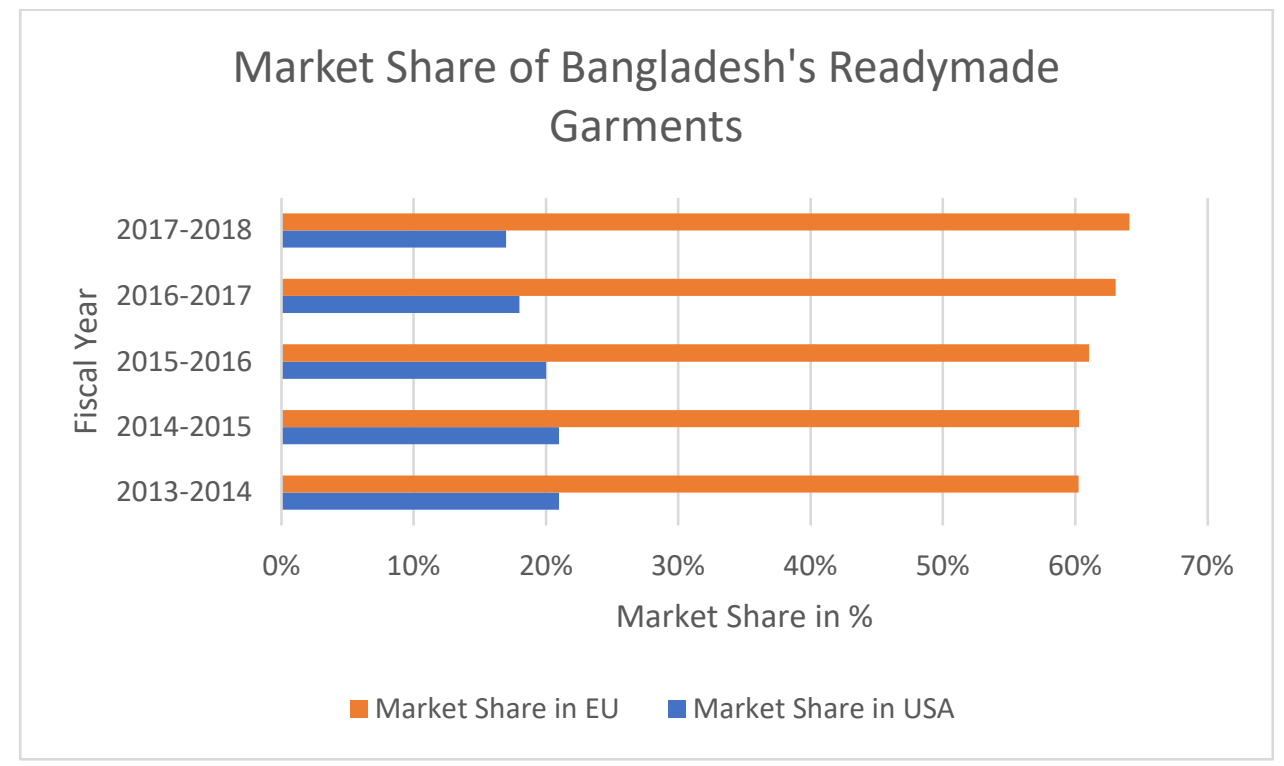

Fig. 3: Market Share of Bangladesh's Readymade Garments (Hossain et al., 2019).

From 1990 to 2004, apparel exports from Bangladesh increased from USD 620 million in 1990 to USD 24.49 billion in 2014 (Rahman et al., 2017). Low wages would have made Bangladesh price competitive. During the period 2004-2007, the Bangladeshi currency depreciated by more than 12\% (Joarder et al., 2010). This should have boosted the competitiveness of Bangladeshi textiles and clothing (T\&C) in the export market. However, Bangladesh could not exploit these advantages because of the obstacles facing its textile companies (Haque and Azmat, 2015). According to World Bank (WB) rankings on ease of doing business, Bangladesh is far behind its neighbours (Table 4).

Table 4: World Bank Rankings in 2019 on Ease of Doing Business (Hossain et al., 2019).

\begin{tabular}{lcccc}
\hline Country & India & Sri Lanka & Pakistan & Bangladesh \\
\hline Score & 67.23 & 61.22 & 55.31 & 41.97 \\
Rank & 77 & 100 & 136 & 176 \\
\hline
\end{tabular}

Apparel manufacturers in Bangladesh face many challenges in running their businesses. The most important of them is low productivity (Hossan et al., 2012). A case study by Karmaker and Saha (2016) found that employment conditions affected employee productivity significantly. However, research revealed that both work environment and job satisfaction influenced productivity, which in turn affected export competitiveness (Hossan et al., 2012). Another research showed low labour productivity is stopping the RMG industry from reaching its export potential (Shafiqul, 2013 and Shafiqul, 2014). High tariffs also undermine export competitiveness and Bangladesh imposes high tariffs on locally manufactured apparels (Rahman et al., 2017).

A range of economic and legal reforms to the labour market and the readymade garments sector in Bangladesh to curb the increasing rate of preventable occupational injuries to factory workers and to ensure injured workers are not denied their rightful compensation by unscrupulous employers (Sharma, 2015). Further states the global supply chain is a long-term relationship between buyers and suppliers which tends to be more buyer-driven than supplier-driven in labour-intensive industries such as the RMG industry (Rahim, 2017). Previously, meeting the buyer's product specifications of colour, design, and accessories was sufficient for winning an export order. However, presently social compliance precedes all other criteria (Hossain and Roy, 2016). While overseas buyers may demand compliance to codes of conduct by suppliers of RMGs, which only can be ensured through social audits (Rahim, 2017).

The apparel sector of Bangladesh can meet its export target of USD 50 billion in 2021 only if structurally unsound factories are strengthened (Ansary and Barua, 2015). Socially sustainable practices have the following economic benefits for readymade garments exporters: higher employee retention, lower employee absenteeism, higher employee productivity, and more profitable export orders (Huq et al., 2014). The Bangladesh Labor Act 2006 was amended to legalize unionization of workers after immense international pressure following the deadly incidents at Rana Plaza and Tazreen Fashions Ltd (Hasan et al., 2018). A root cause analysis performed by Kapuria et al. (2017) concluded that both backward linkage and forward linkage were crucial for the success of the apparel industry. It is believed that lean manufacturing, Kaizen, enterprise resource planning, just-in-time production, and 5S can help streamline operations and thereby improve export competitiveness for Bangladesh's textile sectors (Kader and Akter, 2014; Kapuria et al., 2017). Further research argues that lead time is an important competitive advantage and a shorter lead time will help Bangladeshi readymade garments become more competitive in the export market (Nuruzzaman and Haque, 2009). The combined efficiency of Bangladeshi textile producers' supply 
chain management is $61.85 \%$ which is still below average and the total quality management is more likely to improve the industry's key performance indicators and, in turn, increase export competitiveness (Haque et al., 2011).

The RMG suppliers in Bangladesh have a bad reputation for missing delivery deadlines and a proper system of lead time management can help to boost the long-term competitiveness of textile exports (Kader and Akter, 2014) and they also analysed the factors affecting lead time in the RMG industry, fast fashion apparel is timesensitive, making inventory expensive and emphasizing the need for reducing lead time. Bangladesh imported USD 6 billion worth of cotton from China, Vietnam, Pakistan, Egypt, and India in the fiscal year 2014-2015 to meet the textile sector's raw material needs (Mohibullah et al., 2016). Developing the country's cotton production to curb its dependence on cotton imports (that is, absolute backward integration) will help the RMG industry become more competitive in the export market (Habib, 2009; Kabir and Latifee, 2019).

Many producers of readymade garments in Bangladesh are SMEs who rely on short-term loans to meet working capital needs and to acquire fixed assets. The SMEs have limited access to institutional loans due to excessive paperwork, high cost of financing, expensive collateral requirements, and a long waiting period between loan application and sanction (Chowdhury et al., 2013). The export relationship quality was found to be positively related to both financial and strategic export performance. International buyers must, therefore, address the inconsistency between demanding cheap readymade garments within a short time and expecting social compliance (Haque and Azmat, 2015; Ahamed and Skallerud, 2015).

\section{MATERIALS AND METHODS}

Of the fifty journal articles reviewed for this research, only one has attempted to investigate the relationship between social compliance and export competitiveness of RMG manufacturers in Bangladesh. However, the research mostly used secondary data obtained from academic journals, export statistics from Export Promotion Bureau, and annual sales turnover of fifty-two RMG factories across Bangladesh. Primary data would have been ideal for the scope of this research topic. However, time and resource constraints preclude the collection of primary data through a survey, interviews, and a focus group with a representative sample. A comparison of the sales revenue over five years will show the upward or downward trend of annual sales turnover for each of the fifty-two factories. An upward trend will indicate a positive correlation between social compliance and export competitiveness, whereas a downward trend will indicate a negative correlation between social compliance and export competitiveness.

\section{Conceptual Framework}

Apparel exports from Bangladesh have trebled in volume since the phase-out of MFA and the abolition of GSP. The Table 5 summarizes the situation of Bangladeshi RMG exports to the American market during and after MFA. Table 5: Exports of Bangladeshi RMGs to the US Market (Joarder et al., 2010).

\begin{tabular}{lcc}
\hline & Under MFA (1995-2004) & Post MFA (2005-2008) \\
\hline Growth in RMG Exports & $14 \%$ & $17 \%$ \\
Market Share of RMG Exports & $1 \%$ & $3 \%$ \\
\hline
\end{tabular}

This, however, has not translated into profitability for apparel manufacturers in the country. Over time, profits have diminished or remained stagnant. Bangladesh continues to compete with China whose export prices have decreased much more, making its readymade garments more competitive in the international market. The Table 6 compares the \% decrease in RMG export prices of China and Bangladesh.

Table 6: Decrease in Export Price (Euros per ton) of Readymade Garments (Haider, 2007).

\begin{tabular}{lccc} 
& Export Price in 2001 & Export Price in 2002 & Decrease in Export Price (\%) \\
\hline China & 13,500 & 8,800 & 34.81 \\
Bangladesh & 11,600 & 9,500 & 18.10 \\
\hline
\end{tabular}

Bangladesh is losing market share to relatively cheaper Chinese apparels. The Table 7 shows the decline in exports of Bangladeshi readymade garments to the US market.

Table 7: Exports of Bangladeshi Readymade Garments to the USA (Joarder et al., 2010).

\begin{tabular}{lll}
\hline Year & 1992 & 2008 \\
\hline Total RMG Exports & $42 \%$ & $28 \%$ \\
\hline
\end{tabular}

The RMG exports from Bangladesh decreased by 14\% from 1992 to 2008. If Baral's (n.d.) analysis showed socially compliant RMG producers are more likely to secure export orders, then why did Alam et al.'s (2017) study find textile companies in Bangladesh reluctant to invest in social compliance (which is expensive especially for SME firms)? To identify the reasons behind this, a clear understanding of the following concepts is required: the process of RMG production and export, KPI, lead time, labour productivity, export competiveness, and social compliance. 
The stages in the production and export of RMGs are summarized in the flow chart (Fig. 4).



Fig. 4: Stages in the production of RMG (Nuruzzaman and Haque, 2009).

The four KPI in the RMG industry: quantity and timely delivery, adherence to production targets, quality capability, and on-time shipment. Research suggests the three parameters of success in textile manufacturing are cost, quality, and lead time (Kader and Akter, 2014). Lead time is the time between receiving an export order and dispatching the order to the customer (Haider, 2007). Several studies (Haider, 2007; Nuruzzaman and Haque, 2009; Nuruzzaman et al., 2010; Kader and Akter, 2014; Hossain et al., 2019) indicated that lead time management will increase export competitiveness of Bangladesh's RMG industry. Despite the abundant supply of labour, Bangladesh is struggling to produce quality garments and meet shipment deadlines. The reason for this is labour productivity which is defined as the average output per worker and can be measured in physical or monetary terms (Shafiqul, 2013, Shafiqul, 2014) and Bangladesh has the lowest labour productivity (Table 8).

Table 8: Productivity of RMG Exporting Countries in 2016 (Hossain et al., 2019).

\begin{tabular}{ll}
\hline Country & Per Capita Productivity (in USD) \\
\hline Hong Kong & 110,500 \\
Sri Lanka & 30,700 \\
Indonesia & 24,900 \\
China & 24,000 \\
Pakistan & 16,400 \\
India & 16,000 \\
Myanmar & 10,600 \\
Vietnam & 10,200 \\
Bangladesh & 8,600 \\
Cambodia & 6,200 \\
\hline
\end{tabular}

It is argued the lack of industry-specific skills contributed to the low labour productivity although the minimum wage was raised by $50 \%$ on average across all grades of employees (Hossain et al., 2019). A reliable indicator of a country's export competitiveness is "its share in the global export of goods and services and how that share changes over time" (Hossain et al., 2019). Social compliance is defined as "a continuing process in which organizations endeavour to protect the health, safety and rights of their employees, the community and environment, in which they operate, and the lives and communities of workers in their supply and distribution chains" (Smartsheet, 2019).

\section{RESULTS AND DISCUSSIONS}

The conceptual framework for this research is social compliance facilitates export competitiveness in the following manner (Fig. 5).

\begin{tabular}{|c|} 
Social \\
compliance
\end{tabular}$\longrightarrow \begin{gathered}\text { Increase in export } \\
\text { orders }\end{gathered} \rightarrow \begin{gathered}\text { Increase in } \\
\text { profit }\end{gathered} \longrightarrow \rightarrow \begin{gathered}\text { Increase in export } \\
\text { competitiveness }\end{gathered}$

Fig. 5: Social compliance facilitates export competitiveness. 


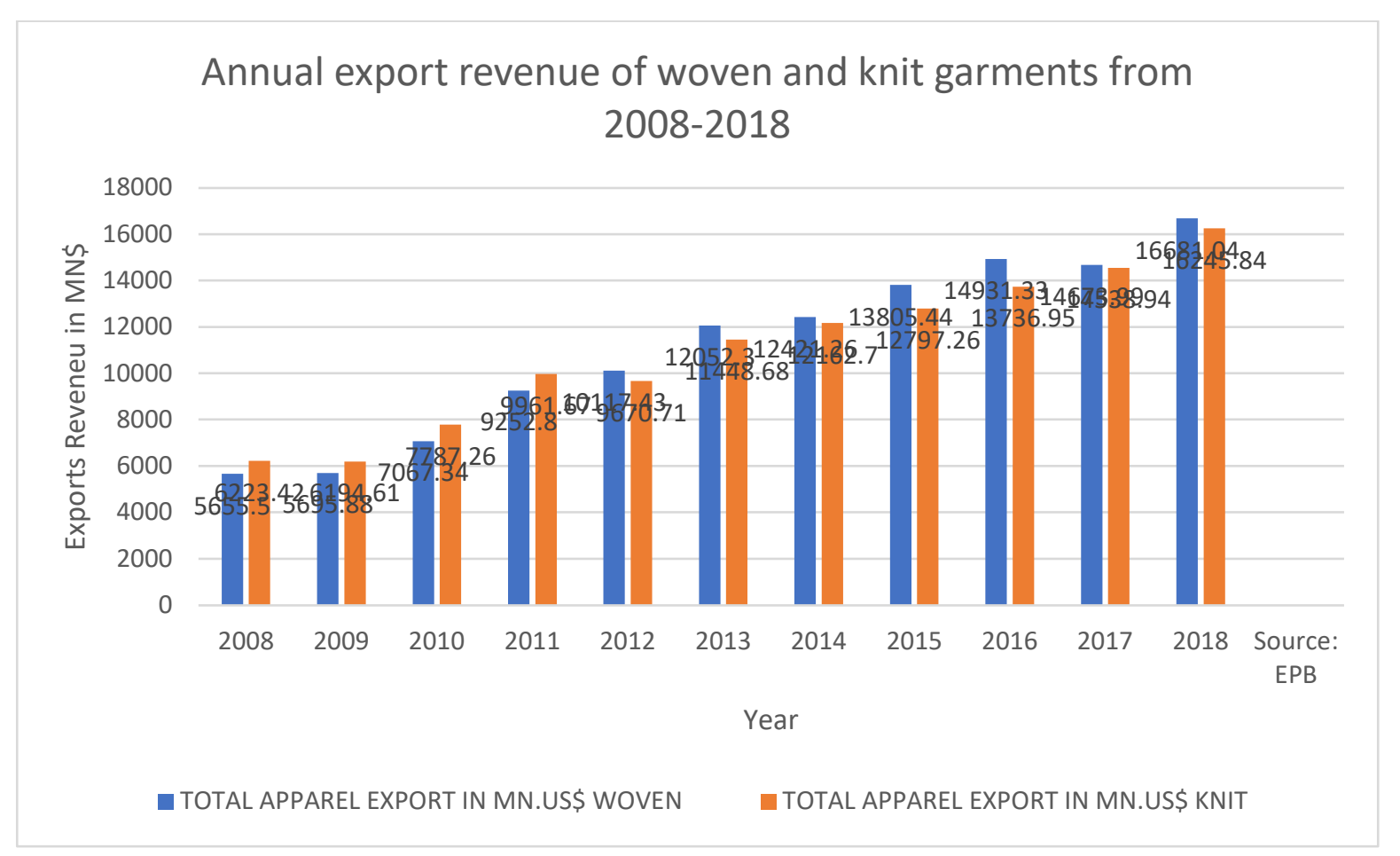

Fig. 6: Annual Export Revenue of Woven and Knit Garments (Source: BGMEA's website)

This research seeks to determine if the correlation between social compliance and export competitiveness in the readymade garments industry of Bangladesh is positive or negative. An upward trend in apparel exports and sales revenue of individual factories across Bangladesh will signify a positive relationship. In other words, social compliance helps RMG manufacturers to compete in the export market. A downward trend, on the other hand, will signify a negative relationship, which means social compliance impedes RMG exporters' efforts to remain competitive in the international market. According to export statistics obtained from the Export Promotion Bureau, total exports over the last ten years have increased at a steady rate for both woven and knitted garments. This is illustrated in the chart below where the blue bars represent the annual revenue from exports of woven garments and the red bars represent the annual revenue from exports of knitted garments (Fig. 6).

In 2008, woven garments fetched USD 5.65 trillion in export earnings and knitted garments earned up to USD 6.2 trillion. In 2009, however, woven garments exports rose by a small fraction to USD 5.69 trillion and knitted garments exports declined to USD 6.1 trillion. The downward trend was reversed when woven garments earned USD 7 trillion and knitted garments earned USD 7.7 trillion from exports in 2010. This upward trend continued in 2011 - USD 9.2 trillion worth of woven garments and USD 9.9 trillion worth of knitted garments were exported. Woven garments exports were buoyant in 2012 earning slightly more than USD 10 trillion. Knitted garments, however, were not as successful because exports decreased from USD 9.9 trillion to USD 9.6 trillion. In 2013, both woven and knitted garments saw a $20 \%$ increase in exports. The country exported USD 12 trillion worth of woven garments and USD 11 trillion worth of knitted garments during the year. In 2014, knitted garments exports rose by USD 700 million to USD 12.1 trillion. In the same year, woven garments exports rose by USD 400 million to USD 12.4 trillion. Woven garments earned more than USD 1 trillion as export revenue in the following year, whereas knitted garments managed to increase its export revenue by USD 600 million. Both woven and knitted garments succeeded in boosting export income by USD 1 trillion each in 2016. Woven garments earned USD 14.9 trillion and knitted garments earned USD 13.7 trillion. In 2017, growth in exports was slower than the previous year with woven garments fetching USD 14.6 trillion (a decrease of USD 300 million) and knitted garments earning USD 14.5 trillion (an increase of less than USD 1 trillion). In the following year, both knitted and woven garments exceeded expectations by earning more than USD 16 trillion (an increase of more than USD 1 trillion). For a clear understanding of the positive (or negative) correlation between social compliance and export competitiveness, the annual sales data of more than fifty RMG companies have been collected from secondary sources and studied. The Table 9 below shows the yearly sales turnover over a five-year period for fifty-two exporters of RMGs, located in Chattogram, Narayanganj and Gazipur, these companies export woven and knitted apparels to countries of the European Union. For purposes of confidentiality, the names of the companies have not been disclosed. 
Table 9: Annual sales turnover of RMG companies in Bangladesh (Euros) Source: Export Promotion Bureau.

\begin{tabular}{|c|c|c|c|c|c|}
\hline \multirow{2}{*}{ RMG Companies } & \multicolumn{5}{|c|}{ Years } \\
\hline & 2015 & 2016 & 2017 & 2018 & 2019 \\
\hline COMP-001 & $4,909,500$ & $5,882,445$ & $6,502,990$ & $7,900,900$ & $8,197,280$ \\
\hline COMP-002 & $8,990,990$ & $10,000,550$ & $11,999,880$ & $13,000,050$ & $14,940,000$ \\
\hline COMP-003 & $18,500,500$ & $20,000,990$ & $21,955,400$ & $23,008,880$ & $25,059,322$ \\
\hline COMP-004 & $31,555,335$ & $33,876,555$ & $35,980,265$ & $38,766,535$ & $40,947,242$ \\
\hline COMP-005 & $5,005,555$ & $6,046,090$ & $7,000,330$ & $8,000,500$ & $9,993,891$ \\
\hline COMP-006 & $22,995,000$ & $25,000,055$ & $26,990,995$ & $28,666,990$ & $30,781,260$ \\
\hline COMP-007 & $10,630,790$ & $12,080,320$ & $13,995,840$ & $15,005,995$ & $16,120,000$ \\
\hline COMP-008 & $255,990,700$ & $275,000,675$ & $288,500,600$ & $300,500,345$ & $334,382,301$ \\
\hline COMP-009 & $2,045,565$ & $3,000,655$ & $4,006,890$ & $5,000,500$ & $6,500,000$ \\
\hline COMP-010 & $15,990,890$ & $17,555,090$ & $19,800,800$ & $20,900,000$ & $22,500,000$ \\
\hline COMP-011 & $124,000,900$ & $125,880,900$ & $127,000,000$ & $128,190,335$ & $130,186,813$ \\
\hline COMP-012 & 137,850 & 140,900 & 142,990 & 144,000 & 150,230 \\
\hline COMP-013 & $1,100,550$ & $1,299,990$ & $1,500,400$ & $1,655,000$ & $1,794,120$ \\
\hline COMP-014 & $132,009,000$ & $135,990,990$ & $138,000,865$ & $140,999,700$ & $143,422,058$ \\
\hline COMP-015 & $45,233,400$ & $47,000,500$ & $48,089,225$ & $49,976,820$ & $52,257,900$ \\
\hline COMP-016 & $37,999,240$ & $39,870,630$ & $41,890,600$ & $43,009,000$ & $45,900,499$ \\
\hline COMP-017 & 723,550 & 750,990 & 779,000 & 800,790 & 892,520 \\
\hline COMP-018 & $25,009,000$ & $26,895,770$ & $28,000,770$ & $29,000,900$ & $30,171,900$ \\
\hline COMP-019 & $10,000,340$ & $11,900,080$ & $13,000,090$ & $13,990,890$ & $15,000,000$ \\
\hline COMP-020 & 800,250 & 900,090 & 985,850 & $1,050,890$ & $1,241,366$ \\
\hline COMP-021 & $20,990,990$ & $22,000,900$ & $23,990,760$ & $25,000,900$ & $27,158,850$ \\
\hline COMP-022 & $5,000,345$ & $6,000,790$ & $7,000,800$ & $8,000,090$ & $8,935,779$ \\
\hline COMP-023 & $1,880,885$ & $2,000,890$ & $2,100,800$ & $2,250,360$ & $2,346,467$ \\
\hline COMP-024 & $6,900,880$ & $7,053,090$ & $8,000,900$ & $9,560,000$ & $10,500,000$ \\
\hline COMP-025 & $7,004,555$ & $8,099,055$ & $9,080,000$ & $10,000,870$ & $10,600,000$ \\
\hline COMP-026 & $10,056,720$ & $11,000,990$ & $12,099,000$ & $13,090,880$ & $14,940,000$ \\
\hline COMP-027 & $2,000,900$ & $2,879,000$ & $3,288,290$ & $4,669,000$ & $5,024,037$ \\
\hline COMP-028 & $38,009,885$ & $39,090,000$ & $40,000,900$ & $41,220,800$ & $42,371,027$ \\
\hline COMP-029 & $4,235,660$ & $5,300,995$ & $6,302,000$ & $7,099,095$ & $8,939,500$ \\
\hline COMP-030 & $3,699,800$ & $4,444,300$ & $5,055,990$ & $6,209,000$ & $7,189,600$ \\
\hline COMP-031 & $22,100,090$ & $23,066,720$ & $24,020,090$ & $25,000,900$ & $26,907,000$ \\
\hline COMP-032 & $4,309,000$ & $5,009,990$ & $6,089,090$ & $7,209,000$ & $8,148,300$ \\
\hline COMP-033 & $1,980,000$ & $2,470,980$ & $3,080,990$ & $4,000,830$ & $4,336,325$ \\
\hline COMP-034 & $4,599,825$ & $5,230,900$ & $6,090,000$ & $7,000,900$ & $7,933,134$ \\
\hline COMP-035 & $1,000,800$ & $1,090,990$ & $2,090,000$ & $3,000,900$ & $3,528,120$ \\
\hline COMP-036 & $3,900,540$ & $4,800,800$ & $5,000,450$ & $5,900,890$ & $6,502,555$ \\
\hline COMP-037 & $3,000,800$ & $3,900,000$ & $4,550,000$ & $5,090,000$ & $6,000,000$ \\
\hline COMP-038 & 603,890 & 700,900 & 777,090 & 867,000 & 953,037 \\
\hline COMP-039 & 823,095 & 900,085 & 999,090 & $1,088,000$ & $1,190,971$ \\
\hline COMP-040 & $180,677,030$ & $181,567,900$ & $182,452,890$ & $183,800,750$ & $184,967,767$ \\
\hline COMP-041 & 90,080 & 95,000 & 97,560 & 99,998 & 101,123 \\
\hline COMP-042 & 724,540 & 798,000 & 845,890 & 900,440 & 949,449 \\
\hline
\end{tabular}




\begin{tabular}{|c|c|c|c|c|c|}
\hline \multirow{2}{*}{ RMG Companies } & \multicolumn{5}{|c|}{ Years } \\
\hline & 2015 & 2016 & 2017 & 2018 & 2019 \\
\hline COMP-043 & $7,443,920$ & $8,052,990$ & $8,805,000$ & $9,430,000$ & $9,926,340$ \\
\hline COMP-044 & $13,444,380$ & $14,250,600$ & $14,780,000$ & $15,309,000$ & $16,000,000$ \\
\hline COMP-045 & $2,277,595$ & $2,880,445$ & $3,333,200$ & $3,909,000$ & $4,394,000$ \\
\hline COMP-046 & $1,000,700$ & $1,122,355$ & $1,609,000$ & $2,000,445$ & $2,504,116$ \\
\hline COMP-047 & $1,302,880$ & $1,599,000$ & $1,809,000$ & $2,000,050$ & $2,432,184$ \\
\hline COMP-048 & $4,677,990$ & $5,000,455$ & $5,750,890$ & $6,000,400$ & $6,502,555$ \\
\hline COMP-049 & $4,733,330$ & $5,000,880$ & $5,499,870$ & $6,090,110$ & $6,642,609$ \\
\hline COMP-050 & $6,009,000$ & $6,500,890$ & $7,000,445$ & $7,899,430$ & $8,382,402$ \\
\hline COMP-051 & 800,900 & 866,940 & 945,555 & $1,000,000$ & $1,095,483$ \\
\hline COMP-052 & $11,225,375$ & $11,900,000$ & $12,099,990$ & $13,000,195$ & $13,211,087$ \\
\hline
\end{tabular}

From the sales figures (Table 9), it is apparent that large, medium, and small firms are operating in the RMG sector of Bangladesh. Since they are exporters of readymade garments as well as members of the prestigious Bangladesh Garments Manufacturers' and Exporters' Association (BGMEA), they are bound by regulations to follow social compliance standards. By carefully analysing the data, the reader will see an upward trend in sales revenue for these apparel makers. Large-scale manufacturers such as COMP-011 ended 2015 with revenue of EUR 124 million and ended 2019 with EUR 130 million - an increase in exports of EUR 6 million over the last five years. Similarly, COMP-014 started 2016 with EUR 132 million to its credit and started 2020 with EUR 143 million in sales revenue. Over five years, the company's exports grew by EUR 11 million. The SMEs have also seen their export earnings improve since 2015. For example, COMP-038 exported EUR 603,890 worth of readymade garments in 2015. Five years later, the company earned EUR 953,037 from its exports. Likewise for COMP-039, whose sales are increased from EUR 823,095 in 2015 to EUR 1,190,971 in 2019. Medium-scale firms such as COMP-045 and COMP-049 had similar sales trends. Exports rose from EUR 2,277,595 in 2015 to EUR 4,394,000 in 2019 for COMP-045. Annual sales revenue for COMP-049 increased from EUR 4,733,330 in 2015 to EUR 6,642,609 in 2019.

\section{CONCLUSIONS}

The aim of this research is to determine if social compliance is helping (or harming) Bangladeshi RMG manufacturers' efforts to remain competitive in the export market. To achieve this aim, the following objectives were formulated:

- To examine the export earnings of Bangladesh's RMG sector during the last ten years.

- To analyze the annual sales turnover of Bangladeshi RMG exporters during the same period.

- To determine if the relationship between social compliance and export competitiveness in the RMG industry is positive or negative.

- To recommend ways in which the RMG industry of Bangladesh can compete in the export market without compromising social compliance.

There is an upward trend in total exports from the apparels sector of Bangladesh during the period 2008-2018 and also a gradual rise in annual sales revenue of fifty-two apparel exporters based in Bangladesh during the period 2015-2019. This indicates social compliance has not harmed export prospects for the individual companies and the economy as a whole. On the contrary, it has helped the RMG industry of Bangladesh build a reputation for ethical trade practices thereby encouraging more countries to import readymade garments from Bangladesh.

Export orders were revoked by overseas buyers in the aftermath of the Rana Plaza incident. Today, importers of readymade garments base their sourcing decisions on product quality, price, lead time, and social compliance. Apart from international recognition for consistent performance, the advantages of being compliant are high employee morale and productivity, low employee turnover, high number of export orders, and favourable relations with government and the community.

It is important to note there are other factors influencing export competitiveness of Bangladesh's apparels sector. Lead time management, supply chain management, backward and forward linkages, sea port inefficiencies, government's fiscal policy, tariff, and currency depreciation affect export competitiveness of apparels exports. Shortening the lead time can boost export competitiveness of Bangladeshi textiles and clothing in the long run. Implementing tried and tested supply chain management systems will help to optimize lead time. Developing the local backward linkage industry will curb exporters' dependence on imported raw materials and thereby shorten lead time further. Imposing high tariffs on locally made apparels undermines export competitiveness. Fiscal policies designed to create a favourable foreign exchange rate will enable readymade garments produced in 
Bangladesh compete in the export market on a stronger footing.

The textiles and clothing sector of Bangladesh has the following prospects: demographic dividend, opportunity for market expansion, and green industrialization. The working age population of Bangladesh is increasing each year. As a labour-intensive industry, the RMG sector can tap into this human resource to support future capacity building projects. An anticipated increase in export prices of Chinese readymade garments will create an export market growth opportunity for Bangladeshi apparels. Considering the climate crisis, a LEED certification will give RMG exporters of Bangladesh an edge over emerging competition such as Vietnam and Cambodia. Short for Leadership in Energy and Environmental Design, LEED is awarded to those companies that invest in resource-efficient, eco-friendly, and low-carbon machinery and management practices.

For the readymade apparels industry to prosper, the following action steps are deemed necessary: a) Reducing the lead time by increasing sea port and airport efficiency, building railway and air freight capacity, and strengthening backward linkages. b) Ensuring a stable supply of energy at fixed prices by meeting domestic shortfalls with imports of liquefied natural gas (LNG), and prospecting for hydrocarbon deposits in the sea to replace natural gas. c) Curbing the heavy dependence on cotton imports by growing the crop locally, and developing synthetic yarn from jute. d) Creating a fund for technical upgrades especially for small and medium enterprises whose external financing options are severely limited by the absence of sufficient collateral. e) Adopting suitable product diversification strategies to cope with rapidly changing consumer tastes and trends in fashion. f) Signing trade pacts (at the government level) with regional blocs for easier market access.

The research findings do not satisfactorily answer the research question dealing with the financial challenges of social compliance for RMG companies in Bangladesh. Primary data will provide the accuracy and relevance required for a research of this scope. A longer timeframe will also help to properly achieve the research aim and objectives

\section{REFERENCES}

Adnan. A. T. M., Rakib, A. and Rahman, M. (2015). Export Trend of Bangladesh: The Dominance of ReadyMade Garments Industry. Research Journal of Economics, Business and ICT 10(1), 25-31.

Ahamed, A. F. M. J. and Skallerud, K. (2015). The Link between Export Relationship Quality, Performance and Expectation of Continuing the Relationship: A South Asia [sic] Exporters' Perspective. International Journal of Emerging Markets 10(1), 16-31.

Ahamed, F. (2013). Could Monitoring and Surveillance be Useful to Establish Social Compliance in the Readymade Garment (RMG) Industry of Bangladesh?. International Journal of Management and Business Studies 3(3), 088-100.

Ahmed, R., Islam, M. T. and Amin, M. A. (2013). The Effects of Market Diversification Activities on Bangladesh [sic] RMG Export. International Journal of Economics and Financial Issues 3(4), 938-948.

Aka, A. M. (2019). Of mortality and unlearned lessons. The Daily Star, 27 Feb 2020. Available at: https://www.thedailystar.net/opinion/perspective/news/mortality-and-unlearned-lessons-1707592

Alam, M. N., Azim, M. T. and Alias, R. B. (2017). Social Compliance in Ready-Made Garment Industry in Bangladesh: Challenges for HR Personnel. Journal of Applied Environmental and Biological Sciences 7(10), 8-18.

Ansary, M. and Barua, U. (2015). Workplace Safety Compliance of RMG Industry in Bangladesh: Structural Assessment of RMG Factory Buildings. International Journal of Disaster Risk Reduction 14(2015), 424-437.

BGMEA. 2019. Trade Information. Retrieved from https://www.bgmea.com.bd/home/pages/TradeInformation

Chowdhury, M. A. M., Ali, M. M. and Rahman, R. (2006). WTO, Post-MFA Era and the Bangladesh RMG Sector: An Assessment of Performance and Challenges. South Asian Journal of Management 13(1), 76-106.

Chowdhury, M. M., Ahmed, R. and Yasmin, M. (2014). Prospects and Problems of RMG Industry: A Study on Bangladesh. Research Journal of Finance and Accounting 5(7), 103-118.

Chowdhury, M. S. A., Azam, M. K. G. and Islam, S. (2013). Problems and Prospects of SME Financing in Bangladesh. Asian Business Review 2(4), 51-58.

Fakir, A. N. M. A., Miah, M. S. and Hossain, M. S. (2013). Export Diversification and Role of Export Processing Zones (EPZ) in Bangladesh. ASA University Review 7(1), 89-105.

Habib, M. R. I. (2009). Backward Linkages in the Ready Made [sic] Garment Industry of Bangladesh: Appraisal and Policy Implications. The South East Asian Journal of Management 3(2), 129-146.

Haider, M. Z. (2007). Competitiveness of the Bangladesh Ready-made [sic] Garment Industry in Major International Markets. Asia-Pacific Trade and Investment Review, 3(1).

Haque, K. M. A., Hossain, M. M., Hossain, M. S. J., Islam, M. A., Hassan, M., Shamshuzzaman, M. and Hossain, M. D. (2011). Performance Evaluation of Bangladeshi Apparel and Textile Supply Chain Network, A Case Study. World Review of Business Research 1(1), 211-218.

Haque, M. Z. and Azmat, F. (2015). Corporate Social Responsibility, Economic Globalization and Developing 
Countries: A Case Study of the Ready Made [sic] Garments Industry in Bangladesh. Sustainability Accounting, Management and Policy Journal 6(2), 166-189.

Hasan, I., Khan, A. N. M. S. N., Karim, M. A., Khan, S. R., Alam, S., Sanjana, B. and Salehin, M. (2018). Health and Safety Compliance in the Readymade Garment Sector of Bangladesh: Practices and Observations. Independent Business Review 11(1-2), 29-38.

Hasan, K. M. F., Mia, M. S., Ashaduzzaman, Rahman, M. M., Ullah, A. N. M. A. and Ullah, M. S. (2016). Role of Textile and Clothing Industries in the Growth and Development of Trade and Business Strategies of Bangladesh in the Global Economy. International Journal of Textile Science 5(3), 39-48.

Hasan, M. M., Mahmud, A. and Islam, M. S. (2017). Deadly Incidents in Bangladeshi Apparel Industry and Illustrating the Causes and Effects of these Incidents. Journal of Finance and Accounting 5(5), 193-199.

Himi, S. A. and Rahman, A. (2013). Workers' Unrest in Garment Industries in Bangladesh: An Exploratory Study. Journal of Organisation and Human Behaviour 2(3), 49-55.

Hossain, M. S., Kabir, R. and Latifee, E. H. (2019). Export Competitiveness of Bangladesh Readymade Garments Sector: Challenges and Prospects. International Journal of Research in Business and Social Science 8(3), 45 63.

Hossain, M. U. and Roy, I. (2016). Supply Chain Management for Sustainable RMG Growth in Bangladesh. International Journal of Science and Research (IJSR) 5(4), 1242-1248.

Hossain, M.F and George, A. (2014). Labor unrest in Ashulia industrial hub. The AIUB Journal of Business and Economics 11(1): 129-147.

Hossain, M.F., George, A., Talukder Alam, M.K. and Mohib, A.A. (2014). Impact of implementing TQM in RMG manufacturing units in Bangladesh. The AIUB Journal of Business and Economics 11(1): 29-52.

Hossan, C. G., Sarker, M. A. R. and Afroze, R. (2012). Recent Unrest in the RMG Sector of Bangladesh: Is this an Outcome of Poor Labour Practices?. International Journal of Business and Management 7(3), 206-218.

Huq, F. A., Stevenson, M. and Zorzini, M. (2014). Social Sustainability in Developing Country Suppliers: An Exploratory Study in the Ready Made [sic] Garments Industry of Bangladesh. International Journal of Operations and Production Management 34(5), 610-638.

Joarder, M. A. M., Hossain, A. K. M. N. and Hakim, M. M. (2010). Post-MFA Performance of Bangladesh Apparel Sector. International Review of Business Research Papers 6(4), 134-144.

Kabir, R. and Latifee, E. H. (2019). Export Competitiveness of Bangladesh Readymade Garments Sector: Challenges and Prospects. International Journal of Research in Business and Social Science 8(3), 45-63.

Kader, S. and Akter, M. M. K. (2014). Analysis of the Factors Affecting the Lead Time for Export of Readymade Apparels from Bangladesh: Proposals for Strategic Reduction of Lead Time. European Scientific Journal 10(33), 268-283.

Kapuria, T. K., Rahman, M. and Haldar, S. (2017). Root Cause Analysis and Productivity Improvement of an Apparel Industry in Bangladesh through Kaizen Implementation. Journal of Applied Research on Industrial Engineering 4(4), 227-239.

Karmaker, C. L. and Saha, M. (2016). A Case Study on Constraints Affecting the Productivity of Readymade Garment (RMG) Industry in Bangladesh. International Journal of Managing Value and Supply Chains 7(3), 69-78.

Kathuria, L. M. (2013). Analyzing Competitiveness of Clothing Export Sector of India and Bangladesh: Dynamic Revealed Comparative Advantage Approach. Competitiveness Review: An International Business Journal 23(2), 131-157.

Mirdha, R. U. (2019). 50 small RMG units shut in six months. The Daily Star, 22 September. Available at: https://www.thedailystar.net/business/news/50-small-rmg-units-shut-six-months-1803517 [Accessed 30 October 2019].

Mohibullah, A. T. M., Takebira, U. M., Abir, S. A. and Jannat, F. (2016). The Consequence of Backward Linkage of RMG Sector in Bangladesh - An Overview. American Scientific Research Journal for Engineering, Technology, and Sciences (ASRJETS) 26(4), 169-185.

Nasreen, Z. (2019). Post-Rana Plaza, what we have achieved and what we haven't. The Daily Star, 24 April. Available at: https://www.thedailystar.net/opinion/news/post-rana-plaza-what-we-have-achieved-and-whatwe-havent-1733647 [Accessed 30 October 2019].

Nuruzzaman and Haque, A. (2009). Lead Time Management in the Garment Sector of Bangladesh: An Avenues [sic] for Survival and Growth. European Journal of Scientific Research 33(4), 617-629.

Nuruzzaman, Haque, A. and Azad, R. (2010). Is Bangladeshi RMG Sector Fit in the Global Apparel Business? Analyses [sic] the Supply Chain Management. The South East Asian Journal of Management, 4(1).

Rahim, M. M. (2017). Improving Social Responsibility in RMG Industries through a New Governance Approach in Laws. Journal of Business Ethics 143(4), 807-826.

Rahman, M. and Hossain, M. (2010). Compliance Practices in Garment Industries in Dhaka City, Journal of Business and Technology (Dhaka) 5(2), 71-87. 
Rahman, M. T., Habibullah, M. and Masum, M. A. A. (2017). Readymade Garment Industry in Bangladesh: Growth, Contribution and Challenges. IOSR Journal of Economics and Finance (IOSR-JEF) 8(3), 1-7.

Rahman, M. Z. (2014). Accord on "Fire and Building Safety in Bangladesh": A Breakthrough Agreement. Nordic Journal of Working Life Studies, 4(1).

Rahman, R., Shahriar, S. and Kea, S. (2019). Determinants of Exports: A Gravity Model Analysis of the Bangladeshi Textile and Clothing Industries. FIIB Business Review 8(3), 229-244.

Rakib, M. A. and Adnan, A. T. M. (2015). Challenges of Ready-made [sic] Garments Sector in Bangladesh: Ways to Overcome. BUFT Journal 3, 77-90.

Shafiqul, I. M. (2013). Labor Incentive and Performance of the Industrial Firm: A Case Study of Bangladeshi RMG Industry. IOSR Journal of Business and Management 7(3), 52-63.

Shafiqul, I. M. (2014). Informal Labor [sic] Incentives and Firm Performance: A Case Study of RMG Industry in Bangladesh. International Business and Management 8(2), 19-27.

Sharma, V. (2015). Imperfect Work Conditions in Bangladesh RMG Sector. International Journal of Law and Management 57(1), 28-37.

Smartsheet, (2019). A Better Life for All: An Introduction to Social Compliance. Available at: https://www.smartsheet.com/social-compliance [Accessed 16 December 2019].

Uddin, M. (2018). The debate on extending Accord-Alliance. The Daily Star, 20 November. Available at: https://www.thedailystar.net/lifestyle/perspective/news/the-debate-extending-accord-alliance-1662787 [Accessed 30 October 2019]. 